\title{
Frequent Breaches in Irrigation Canals in Sindh Pakistan
}

\author{
Riaz Bhanbhro"1,2, Nadhir Al-Ansari1*, Sven Knutsson'1 \\ ${ }^{1}$ Department of Civil, Environmental and Natural Resources Engineering, Luleå University of Technology, \\ Luleå, Sweden \\ ${ }^{2}$ Quaid-e-Awam University of Engineering, Science \& Technology, Nawabshah, Pakistan \\ Email: ${ }^{*}$ nadhir.alansari@ltu.se
}

Received 8 January 2014; revised 5 February 2014; accepted 4 March 2014

Copyright (C) 2014 by authors and Scientific Research Publishing Inc.

This work is licensed under the Creative Commons Attribution International License (CC BY).

http://creativecommons.org/licenses/by/4.0/

(c) (i) Open Access

\begin{abstract}
Every year, a number of breach failures occur in Irrigation Canals in Sindh. Those failures cause displacement of thousands of people, destruction of properties, land, and damage to costly crops that worth millions Rupees. In addition to that, breach failures also can cause water shortages when the failure occurs during the peak demand period. There are various causes of embankment failures which include overtopping, internal erosion, structural defects and piping. State of art for breach failures is presented in this paper and suggestions for prediction of breaches in context to canals in Sindh are discussed. Seepage and slope stability analyses are recommended for a long-term breach predictions.
\end{abstract}

\section{Keywords}

\section{Canal Breaches; Embankment Failures; Long Term Breach Prediction; Irrigation System Sindh}

\section{Introduction}

Sindh is the province of Pakistan and part of Indus Basin system. There are three barrages and 14 main canals which irrigate about 5 million hectares of area in Sindh [1]. Each year, breach failures in canals in Sindh are reported resulting loss of people, property, land and crops from flooding. Irrigation network map is shown in Figure 1. Embankments are constructed to withstand against water for several purposes including irrigation, supply and flood defense to protect people, land, crops, and property [2] [3]. These embankments can survive up to some limited safety levels and are subject to decay with time and might fail due to several triggering mechanisms [4] [5]. Most frequent embankment failures are caused by overtopping and internal erosion [6] structural de-

\footnotetext{
"Corresponding author.
} 


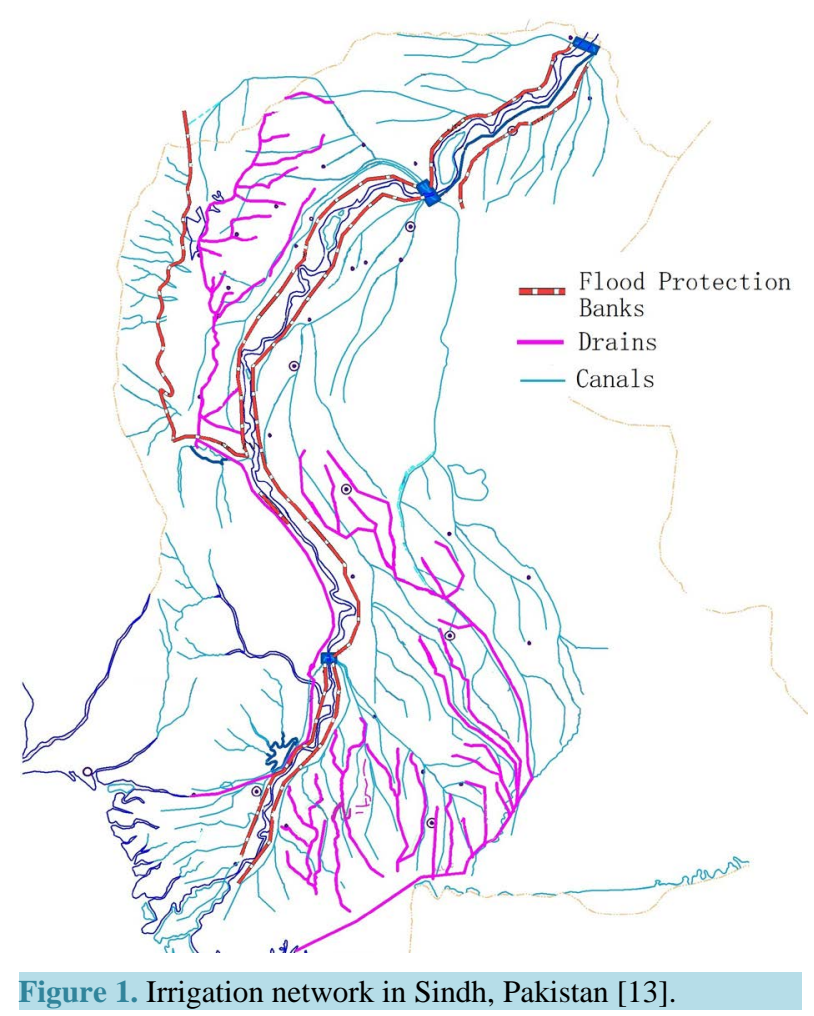

fects and piping [2]. Breach process and breach rate can depend upon various factors including hydraulic conditions, materials, geometry, compaction, water content, density strength etc. [7] [8].

There is a need to improve understanding of breach failure warning particularly for canals in Sindh. This can be achieved by considering factors (and causes), causing the breach failures. Many researches carried out previously on this subject and had developed models for prediction of erosion rates, time to failure and modes of failure. Other studies on this problem were conducted using laboratory experiments and developing field models, which are summarized by [2] [9] [10].

However, there is need to conduct such type of studies for canals in Sindh towards safety and prediction of breaches.

This article presents the state of art study for breach failures in context to canals in Sindh. Attempt have been made to develop some guidelines for long-term breach predictions prior to failure. Various factors are discussed that can predict upcoming failure and some suggestions are given that can be included in Bund Manual. Bund Manual is official document for construction and regulation of the irrigation systems in Sindh [12]. Some preliminary basic laboratory tests are recommended to find out the strength of embankment materials in order to conduct seepage analysis and perform slope stability analysis

\section{Breaches in Canals in Sindh}

Every year, a number of breaches in canals of Sindh are reported, causing floods and displacement of thousands of people, causalities of people and animals, destruction of crops of worth of millions of rupees and property losses. A view of breach in Mirwah canal in Sindh is shown in Figure 2 and some of recent breach failures are summarized in Table 1.

\section{Common Causes of Breach Failures}

There are several reasons involved for canal breaches in irrigation canals of Sindh. Breach data presented in Table 1 show that the majority of failures occurred during flood seasons or when water is being released at full supply levels in canals or even in excessive quantity. Generally, embankments of canals in Sindh are built as homogenous usually constructed with earth (clay, silt and sand). Most frequent embankment failures are caused 


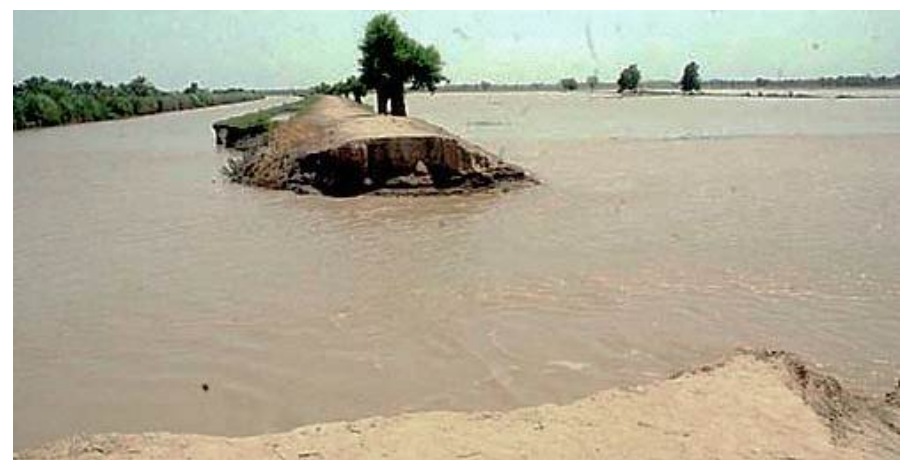

Figure 2. View of breach along Mir Wah Canal, Sindh [11].

Table 1. Some of recent breach failures in Canals in Sindh.

\begin{tabular}{|c|c|c|c|}
\hline Canal and its location & Description and Damages & Year & Source \\
\hline $\begin{array}{c}\text { Rohri Canal } \\
\text { At RD 723-724 }\end{array}$ & $\begin{array}{l}\text { Widened up to } 200 \mathrm{ft} \text { with flow around } 5000 \text { cusec from breach point. } \\
\text { Caused displacement of 40,000 people, more than } 25 \text { villages were } \\
\text { completely flooded and thousands of acres of cotton crops were destroyed. } \\
\text { Flow in canal was around } 13000 \text { cusec before breach. }\end{array}$ & May 2012 & $\begin{array}{l}\text { The Express } \\
\text { Tribune (2012) } \\
\text { [14] }\end{array}$ \\
\hline $\begin{array}{l}\text { Rohri Canal } \\
\text { Near Kumb Daron }\end{array}$ & $\begin{array}{l}\text { People from } 40 \text { villages were displaced, } 400 \text { houses destroyed. } \\
\text { Thousands of acres of crops were damaged. }\end{array}$ & September 2007 & Rajput (2012)[15] \\
\hline $\begin{array}{l}\text { Rohri Canal } \\
\text { RD } 752\end{array}$ & 50 villages were submerged under water and crops were destroyed. & July 2008 & Rajput (2012) [15] \\
\hline $\begin{array}{l}\text { Rohri Canal } \\
\text { Near Kesana mori }\end{array}$ & $\begin{array}{c}\text { Failure occurred during peak demand season and there was already } \\
\text { water shortage. Huge quantity of water wasted followed by damages } \\
\text { to many villages and crops. }\end{array}$ & 2007 & Rajput (2012) [15] \\
\hline $\begin{array}{l}\text { Rohri Canal } \\
\text { RD } 839\end{array}$ & $\begin{array}{c}\text { Caused } 2 \text { months of emergency in the vicinity and Tando Adam city } \\
\text { was submerged in water. }\end{array}$ & 1990 & Rajput (2012) [15] \\
\hline Mir Wah Canal & $\begin{array}{l}\text { A } 100 \mathrm{ft} \text { breach in Mirwah canal. It destroyed } 20 \text { houses along with damages } \\
\text { to date palm orchards and flooding } 500 \text { acres of agricultural land. Figure } 2\end{array}$ & June 2011 & Dawn (2011) [11] \\
\hline $\begin{array}{l}\text { Mir Wah Canal } \\
\text { RD240 }\end{array}$ & $\begin{array}{l}100 \mathrm{ft} \text { breach was reported. Thousands of acres of land were inundated with } \\
\text { water causing sever damages to crops of sugarcane, jute and cotton. } 400 \\
\text { houses nearby were flooded and } 100 \text { mud houses were damaged. }\end{array}$ & July 2010 & $\begin{array}{l}\text { The Express } \\
\text { Tribune (2010) } \\
\text { [16] }\end{array}$ \\
\hline $\begin{array}{l}\text { Jamrao Canal } \\
\text { RD 164-165 }\end{array}$ & $\begin{array}{l}\text { Crops of rice and cotton standing on } 400 \text { acres of land were washed away. } \\
\text { More than } 1000 \text { families of } 10 \text { villages were affected by the breach }\end{array}$ & July 2012 & $\begin{array}{l}\text { The News (2012) } \\
\text { [17] }\end{array}$ \\
\hline Jamrao Canal & $\begin{array}{l}\text { The gushing water from } 300 \mathrm{ft} \text { wide breach in Jamrao canal not only } \\
\text { inundated agricultural land but also caused damage to wildlife sanctuary } \\
\text { washing away jackals, rabbits and perished the eggs of crocodiles. }\end{array}$ & May 2011 & $\begin{array}{l}\text { Business } \\
\text { Recorder } \\
\text { (2011) [18] }\end{array}$ \\
\hline Nusrat Canal & $\begin{array}{l}\text { Similarly a breach in Nusrat canal was recorded by Sama TV on } 22 \\
\text { September } 2010 \text { which caused around } 200 \text { acres of flood damaging crops. }\end{array}$ & September 2010 & $\begin{array}{l}\text { Saama TV (2010) } \\
\text { [19] }\end{array}$ \\
\hline $\begin{array}{l}\text { Twin jamrao Canal } \\
\text { Mile } 33\end{array}$ & & July 2012 & Rajput (2012) [15] \\
\hline
\end{tabular}

by overtopping, internal erosion [6], structural defects and piping [2].

\subsection{Internal Erosion and Piping}

Internal erosion in embankments can be originated by several factors such as backward erosion, leakage because of hydraulic fracturing, slope instability, high permeability region due to improper compaction, internal instability, hydraulic gradient, soil type and degree of saturation [6] [20]. Piping can be originated when hydraulic gradient of seepage is greater than hydraulic gradient of that soil [21].

Apart from earlier mentioned failures for internal erosion and piping, uncontrolled animal activity has always been a core issue of the canals in Sindh, where burrowing animals [2] [20] [22] like rats, earth worms burrow and dug the tunnels and holes [22] [23]. These holes cause weakening of embankments (Figure 3). This ultimately 


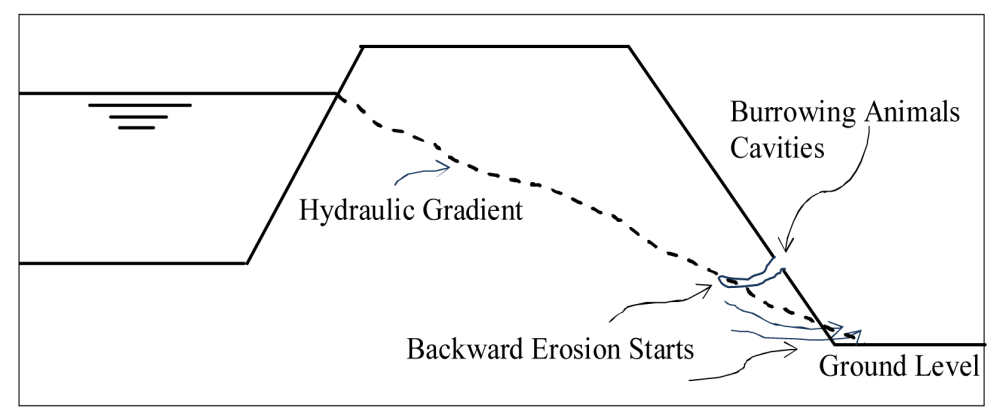

Figure 3. Some observed scenarios in canal systems in Sindh.

originates the flow when such cavities and holes come in contact with hydraulic gradient leading to breach failure by developing internal erosion and piping.

Most of the embankments for main canals in Sindh had deteriorated due to wear and natural ground levels had been lowered due to several reasons including agricultural activities. Due to lowering of ground levels near toe of embankments, hydraulic gradients are exposed to space. Since, the process that flow of water though embankment is natural as water stays against embankment almost every time, it start to seep and with time it develops small pathways for water to flow out.

Seepage energy can cause the finer particles to flow from upstream to downstream of embankment, removal of particles cause increase in diameter of pipe resulting collapse of crest roof [2]. Embankments fail due to wash out of its materials by flow of water [2] followed by development of internal erosion. The procedure of internal erosion and piping involves four stages; initialization of erosion, continuation, progression to enlarge leakage and failure/breach formation [6].

\subsection{Overtopping}

Water can overtop the embankments due to several reasons. Those reasons can be the settlement of embankments, erosion of top surface of embankment and high flood levels in the canal. High monsoon rainfalls can also take active part to erode top most layer of the embankments [24]. Deposition of sediments in the bed of a canal may cause water to overtop even canal runs at designed capacity. Non cohesive embankments usually have surface erosion when they are subject to overtopping whereas cohesive embankments have head cut erosion, highly compacted non-cohesive soils might also erode in head cut [2]. Several tests were conducted by [25] to describe breach process during overtopping. Initially erosion starts from downstream side making some micro rill erosion on downstream slopes and as a result, series of rills which gradually becomes master rill, eventually initiating main headcut resulting widening of canal. Head cut gradually migrate to upstream crest of embankment ultimately causing breach.

\subsection{Frequent Drying and Wetting}

Sindh is situated in subtropical region where summers are hot and winters are cold.

It is expected to observe climate changes with rise in temperatures and drier weather. Drier summers and wet winters possibly result in larger changes of pore water pressure and moisture content in clay soils that causes more common slope serviceability problems and damages [26].

One reason for drying and wetting can be because of climate changes i.e. summers and winters. Another reason of frequent drying and wetting within the embankment is due to the fluctuation of the water flow in canals causing change in moisture content (Figure 4). Drying and wetting within embankment can reduce or increase water content and degree of saturation which are also factors that attribute to initialize flow path enlargement that causes erodibility [6]. Higher cycles of moisture in old clays can cause problems like shrink and swell [26]. Tension cracks are likely to develop during long dry periods for high plasticity clay soils [24]. Series of tests were conducted by [27] and it indicated that drying and wetting can reduce long-term shear strength for high plastic clays.

\subsection{Trees}

Cutting down of trees can attribute towards breach failure. Tree roots are subject to decomposition upon cut- 


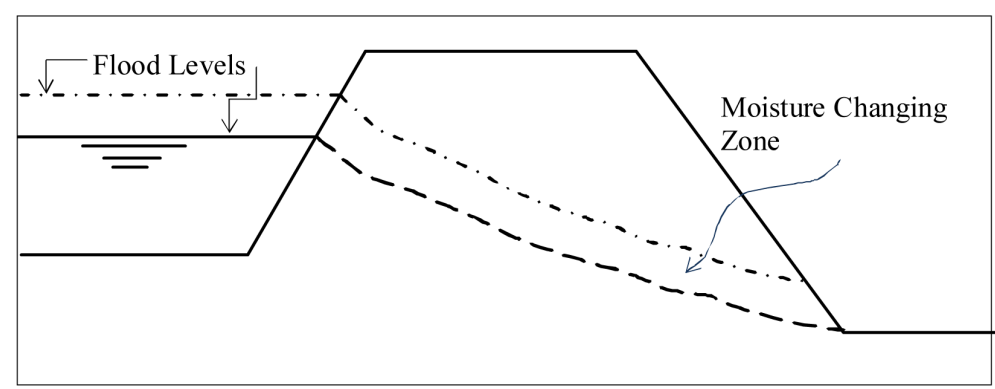

Figure 4. Moisture changing zone due to change in flood level in canal.

ting that can leave root holes [22]. These root holes can act as seepage flow path, that might lead to the progresssion of erosion ultimately that leads to failure. On the other hand, there are also positive effects of tree planting on the embankments on the stability and maintenance. It can control erosion and also provide protection against burrowing animals [28]. However, in windy areas plantation of trees can be harmful due to chances of breaking of trees.

\subsection{Structural Defects}

Small structures (modules/conduits etc.) constructed within embankment of the main canals for off taking water courses can cause the leakage. This may be due to weak bond between the hydraulic structure and the embankment. Chances are high for initialization of leakage in cases when canal runs at designed full supply level or even in excess. Structural defects might include differential settlements followed by cracks and weaken layers that originate internal erosion and piping which causes failure [2].

\subsection{Sand boils/Bubbles}

According to McCook [21] sand boils are phenomenon related to piping and that may develop at downstream side of the embankments, which might lead to failures due to sudden unexpected water levels. However, sand boils do not cause breach failures always; they can be immediately treated by providing sand bags. Water leaks from foundation of embankment through a sand stratum towards downstream side and forms bubbling spring. In such underground leaks, water streams flows like fountain and carries sand along its flow. These water leaks look like small volcanoes emitting water and sediments [2] [12]. Saturation of foundation materials may cause slope instability and sliding [2]. Such type of leak that led to breach was observed at a location mile 13/4 of the left bank bund near Moro in 1942 [12]. Chances of breach are higher when underground flow of water is muddy; similarly less if the water flow is clear.

\subsection{Exposed Wave Action in Coastal Areas}

Islam [22] stated that in coastal areas tidal waves might damage the embankments. Hydraulic loads are gradually applied on toes and slopes due to action of tidal waves. On the other hand, cyclonic storms in coastal areas if occurs recurrently causes enormous hydraulic loads by acting on water surface. These ultimately hit the embankments, and if there is overtopping, the embankment gets destroyed. High velocity flow in coastal areas often causes erosion of banks by undermining.

\subsection{Other Causes of Failures}

High energy flow through canals can cause significant erosion near banks of channel that may lead to sliding inside the canal followed by bank failure. Regular monsoon rains create surface runoff that causes sheet erosion and formation of rills on the poor protected embankments that can weaken the banks leading to failures [22]. Earth quakes, maintenance and control against local weaknesses, vegetation can also sometimes be a cause of breaching [2]. Islam [22] summarizes various other factors that lead to failures. They are:

- Human interference factor: This is most common where the people living near by banks of canals use embankments as their main travel path and crest serving as rural communication road between villages.

- Heavy movement during dryer seasons: This can cause decaying of embankment. 
- Uncontrolled cattle movements/grazing slowly affect the shoulders and toes of banks.

- Public cuts: These cuts are frequently observed, and they weaken the embankments which lead to slow and continued erosion [22] [23]. These cuts can lead to a breach during heavy floods or storm. The cuts are usually made for personal benefits of yielding by individuals owning crops nearby.

- Other factors: Apart from those factors mentioned above, poor planning and maintenance, faulty design and construction, proper supervision, inappropriate soil materials, proper compaction [2] [22] [23] are also factors that contribute to a breach or failure.

\section{Prediction of Breach Failures in Embankments of Canals}

It is very difficult to predict upcoming breach for any embankment/levee, although it is not a new technique. There can be several factors involved that indicate the upcoming failures [10]. Extensive studies have been made on modeling of breach failures; almost all of them represented the breach formation methods, models and to evaluate risks related to breach failures. These studies included the laboratory tests and modeling for overtopping breach, internal erosion, piping failure and breach propagation which are summarized by [2] [9] [10]. However, very fewer studies had been conducted to predict a breach failure long time before its failure. Short term breach prediction might include the surveillance and monitoring for any seepage, leaks, and erosion from the embank- ments at regular basis.

\section{Long-Term Breach Predicts}

This method might involve developing an equation of physical characteristics or data of earlier failures [10]. That data may include a complete previous flood record, earlier failure histories of the location [10], discharge during previous failures, the height of embankment etc. Previous records of failures might provide some hints towards expected upcoming breach. For example, it had been observed that many breach failure had been reported between locations of RD 600 to RD 900 on both sides along Rohri Canal in the past few years. All these failures were reported during monsoon/high flood seasons. Depending on any mode of the failure, it still can be linked to expect the upcoming failure.

There can be several reasons for failure, improper maintenance/surveillance, poor design, high permeable material used for the construction of embankments in this area, and creep settlements cannot be neglected. Although these failure reasons are still unanswered at the moment for the said canal, and a comprehensive study of area is required. A broader idea, which might predict breach long time before it takes place might include a comprehensive preliminary study of the site. The study should include, checking the free board according to high flood level design, detailed soil investigation/classification, hydraulic conductivity within embankment, compaction ratio, seepage paths to verify if the seepage gradients are exposed to outer slope, monitoring the pore water pressure within embankment, and to analyzing slope stability after performing laboratory tests. Upon receipt of these results, an expected failure can be predicted and avoided accordingly.

\section{Remedial Measures/Suggestions}

\subsection{Heavy Surveillance}

Continuous surveillance should be performed at regular basis, especially during monsoon/flood seasons. Surveillance may include, monitoring of free board, water levels, and downstream seepage/boils. Visual surveillance and measurement is a common method to detect internal erosion and piping in embankments. However, in most cases it is recognized at the stage when erosion has already been initiated and pipe has progressed, this can also depend on several factors [6]. Immediate measures should be taken to stop the piping once it is detected as usually pipes are the last visible stage followed by failure if not treated. Special attention should be paid to surveillance during high flooding in canals as most of piping cases through embankments are due to high levels [6].

\subsection{Operation and Maintenance}

A canal should be continuously monitored throughout its lengths. Weak locations should be determined and filled accordingly, the free boards should be maintained throughout according to its designed capacity and high flood levels. If any canal is subject to sedimentation, it should be dredged in order to maintain desired dis- 
charges. Any cuts and rills on the embankment due to rain should properly be treated.

Decayed trees along embankments should be properly removed. Scouring of berms is usually observed at canal curves. Measures should be taken to minimize the erosion at such places; this can be done by providing rip raps on upstream side. Canals should be properly operated from head regulators i.e. sudden draw down and sudden over flow can cause severe damages to canal embankments. If there is any breach in any off taking canal from the main canal, it should not be closed immediately as it may increase the flow in the main canal that ultimately can cause breaches in main canal as well [29].

\subsection{Proper Compaction}

Compaction can significantly improve the engineering properties of earthen materials [30]. Degree of compaction has significant effects on the erodibility of material used for the construction of embankment. Soil erodibility is the main material property in defining the piping and internal erosion of earthen embankments [31]. All soils are susceptible to erosion [20], measures should be taken to reduce the erodibility of soils. This can be achieved by increasing the degree of compaction. Presently compaction dry density ratio of $85 \%$ is used for construction and rehabilitation works along canals in Sindh. However, any compaction dry density ratio less than $90 \%$ is very poorly compacted that appears to be fast erodible irrespective of any soil type [6]. Poorly compacted soils (less than 95\%) are more likely influence to erosion; 95\% - 98\% of standard compaction density ratio is neutral whereas $98 \%$ or greater than $98 \%$ are less likely to pipe or erosion [6] [32] [33]. Series of laboratory tests were conducted by [30] [34] [35], concluded that soils which are compacted on wet side of optimum moisture content are less erodible as compared to dry side of optimum water content. Also the rate of change of erodibili- ty versus dry density is quicker on dry side as compared to wet side. Figure 5 shows and illustration of same dry density at points a and b; however, the only difference is water content. Many upcoming failures can be avoided by selecting proper compaction ratios in construction or rehabilitation works; it is recommended that at least 95\% degree of compaction on wet side should be used. Apart from strength, improved compaction can also offer more resistance to burrowing animals to create tunnels and holes [36].

\subsection{Soil Texture and Gradation}

Soil gradation is one of key factors for determination erodibility [30]. Texture and gradation of soils used in construction of canals should be analyzed. As seepage through embankments can be high if poorly graded or gap graded soils are used. Study should be conducted to find soil properties related to gradation curves, remedial measures should be taken accordingly. Materials which are used in construction or rehabilitation works along canals should be used as high plastic of liquid limit $50 \%$ or more in the downstream zone of embankments [6], as it can increase time for expected development of breach.

\subsection{Bio-Tech Reinforcements and Crest Sloping}

Islam [22] defines that embankment erosions can be reduced by vegetation and plantation on embankments. Severe erosions of monsoon rainfall can be significantly reduced by surface vegetation; this surface vegetation can be usually a mat of well-maintained grasses. This continuous mat of grass works as bio tech reinforcements for embankments against runoff erosion due to overtopping or heavy rain falls. Providing crest sloping (Figure 6) can assist drainage to flow towards the upstream side, it helps in reducing the velocity of overtopping waters; usually it should be provided with slope of 1 in 20 [37].

\subsection{Detailed Laboratory Investigations}

To find stability of slopes of embankments and calculate the factors of safety, some advanced laboratory investigations are recommended. Once the laboratory data are available, then, weak zones and potential embankment failures can be detected. There is strong need to perform laboratory investigations as up to date there is no available data for the laboratory investigations for the canals in Sindh in literature. These laboratory investigations may include, 1) liquid limits and plastic limits; 2) gradation curves; 3) degree of compaction at present level; 4) strain rates upon application of loads; 5) hydraulic conductivity; 6) particle shape and mineralogy; and 7) shear strength parameters of soils. For determination of strength parameters, both direct shear and triaxial tests should be performed. 


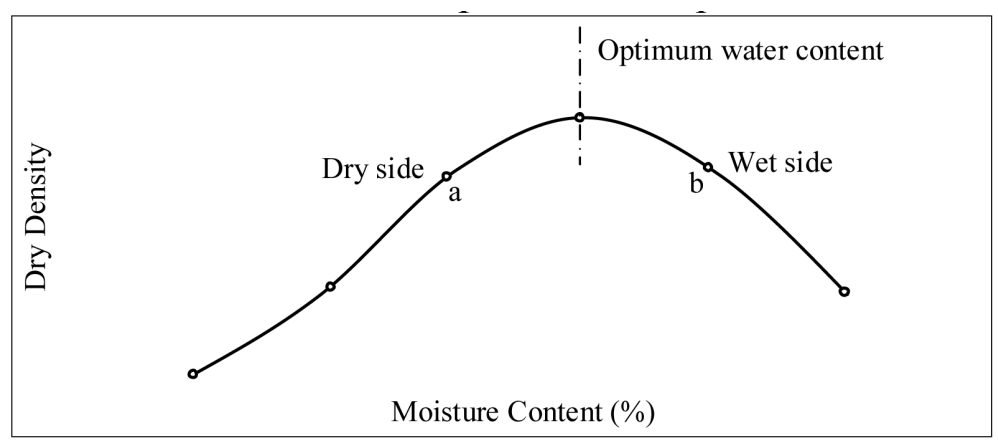

Figure 5. Dry density vs. water content.

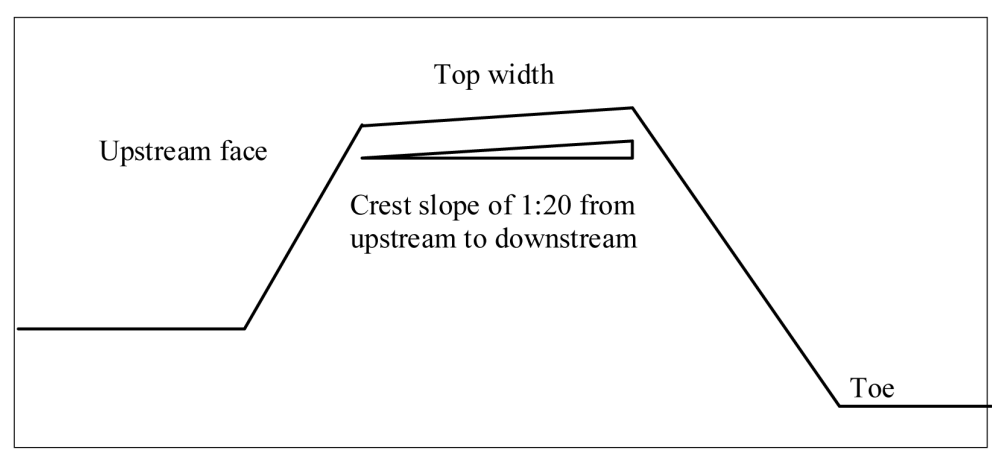

Figure 6. Top width section, crest slope, after [37].

\subsection{Seepage Analysis}

Complete study of seepage paths should be carried out. The saturation gradient in present construction or rehabilitation works of canals is assumed theoretically as suggested in Bund Manual [12], which is the official document for irrigation and drainage department, Government of Sindh. However, seepage gradient can vary tremendously depending on the compaction ratio, material gradation, and soil types.

So it is very necessary to conduct the study for seepage analysis in order to find relatively more realistic seepage gradient for the future constructions and for the existing canals. Embankment materials and its engineering properties can vary along its lengths. In order to perform the analysis for seepage gradient; material properties should be determined by taking several samples along its length to determine material gradation and hydraulic conductivity. Seepage analysis can be performed by using finite element method, and there are various computer programs available that can perform the seepage analysis. Computer programs can reduce enormous time and money [38].

\subsection{Slope Stability Analysis}

Slopes have tendency to slide due to the effect of gravitational and/or other forces. Failure mode of breach at location RD 723 of Rohri canal was due to sliding [15]. There could have been several failures which are not reported as most of failures modes of breaches are not reported. The engineering properties of materials used in construction are controlled by compaction and methods of construction. However, these properties can change with time due to several factors (seepage pressures, deterioration, draw down effects and creep etc.). It is thus important to analyze the slopes for stability of the present conditions. The analyses can be performed for these critical conditions such as 1) long term conditions; 2) effective normal and principal stresses within embankments; 3) effects of sudden draw down or vice versa; 4) seismic disturbances if any 5) creep; and 6) for safety factors. Safety measures can be taken accordingly after receipt of the results from stability analysis.

\section{Conclusions/Discussions}

Many beach failures occur every year in Canals in Sindh. There are various reasons for failures including over- 
topping, internal erosion and piping, structural defects and high energy flows in canals. Prediction of breaches is not a new technique; it requires several factors and reliable data. It can be further divided as short term prediction and long term prediction. Short term breach prediction may include the monitoring and surveillance for any seepage or erosion along the embankments. Long term breach prediction may include a detailed study about the location, materials, construction methods, rate of erosions, compaction, hydraulic conductivity and strength parameters, then to develop an equation to correlate the upcoming failure. Some initial laboratory studies are recommended for canals in Sindh in order to conduct detailed seepage studies and slope stability analysis, which might predict weak zones in embankments that can reduce potential breach failures.

\section{Acknowledgements}

The research presented was carried out as a part of "Swedish Hydropower Centre-SVC". SVC has been established by the Swedish Energy Agency, Elforsk and Svenska Kraftnät together with Luleå University of Technology, The Royal Institute of Technology, Chalmers University of Technology and Uppsala University.

\section{References}

[1] Steenbergen, F. (2014) Water Charging in Sindh, Pakistan-Financing Large Canal Systems. http://www.metameta.nl/wp-content/uploads/2012/02/MetaMeta_Watercharging_Sindh.pdf

[2] Wu, W., Altinakar, M., Al-Riffai, M. and Bergman, N. (2011) Earthen Embankment Breaching. Journal of Hydraulic Engineering, 137, 1549-1564. http://dx.doi.org/10.1061/(ASCE)HY.1943-7900.0000498

[3] Mohamed, M., Samuels, P., Morris, M. and Ghataora, G. (2002) Improving the Accuracy of Prediction of Breach Formation through Embankment Dams and Flood Embankments. Proceedings International Conference, Fluvial Hydraulics, Louvain-la-Neuve, Belgium, 663-673.

[4] Foster, M., Fell, R. and Spannagle, M. (2000) The Statistics of Embankment Dam Failures and Accidents. Canadian Geotechnical Journal, 37, 1000-1024. http://dx.doi.org/10.1139/t00-030

[5] Allsop, W., Kortenhaus, A., Morris, M., et al. (2007) Failure Mechanisms for Flood Defense Structures. FLOODsite Report.

[6] Fell, R., Wan, C.F., Cyganiewicz, J. and Foster, M. (2003) Time for Development of Internal Erosion and Piping in Embankment Dams. Journal of Geotechnical and Geoenvironmental Engineering, 129, 307-314. http://dx.doi.org/10.1061/(ASCE)1090-0241(2003)129:4(307)

[7] Hunt, S., Hanson, G. and Temple, D. (2006) Breach Widening Observations Related to Clay Core Earthen Embankment Tests. FLOODsite project report T04_06_01, April. http://hikm.ihe.nl/floodsite/data/Task4/pdf/failmechs.pdf

[8] Hanson, G., Cook, K. and Hunt, S. (2005) Physical Modeling of Overtopping Erosion and Breach Formation of Cohesive Embankments. Transactions of the American Society of Agricultural Engineers, 48, 1783-1794. http://dx.doi.org/10.13031/2013.20012

[9] Wahl, T.L. (2007) Laboratory Investigations of Embankment Dam Erosion and Breach Processes. CEA Technologies inc., dam safety interest group, CEATI report no. T032700-0207A, 60 p.

[10] Morris, M. and Hassan, A. (2002) Breach Formation through Embankment Dams \& Flood Defence Embankments: A State of the Art Review. HR Wallingford, IMPACT Project Workshop, Wallingford.

[11] Dawn (2013) Canal Breach Inundates 500 Acres. http://dawn.com/2011/06/12/canal-breach-inundates-500-acres

[12] Bund Manual (2008) 4th Edition, Irrigation and Power Department, Government of Sindh, Pakistan.

[13] Sindh Irrigation and Drainage Authority (SIDA) (2013) http://www.sida.org.pk/download/maps/IrrigationNetworkPlanMap.jpg

[14] The Express Tribune (2013) More than 30000 People Have Been Displaced by Breach in Rohri Canal. http://tribune.com.pk/story/378786/more-than-30000-people-have-been-displaced-by-breach-in-rohri-canal

[15] Rajput, M.I. (2012) Translated from Sindhi Book (Saal 2011 wari barsatibod ae sindh ja soor). Sindh National Academy (Trust), Hyderabad.

[16] The Express Tribune (2013) 400 Houses Damaged by Canal Breach in Khairpur. http://tribune.com.pk/story/26853/400-houses-damaged-by-canal-breach-in-khairpur

[17] The News (2013) Breach in Jamrao Canal Inundates Several Villages. http://www.thenews.com.pk/Todays-News-2-121534-Breach-in-Jamrao-canal-inundates-several-villages

[18] Business Recorder (2013) More than 300 ft Jamrao Canal Breach Damages Wildlife Sanctuary. 
http://www.brecorder.com/pakistan/general-news/14397-more-than-300ft-jamrao-canal-breach-damages-wildlife-sanct uary.html

[19] Saama, T.V. (2013) Naushero Feroze’s DKM Submerged as Nusrat Canal Breaches. http://www.samaa.tv/nadeemmaliklive/Naushero-Feroze\%E2\%80\%99s-DKM-submerged-as-Nusrat-Canal-breaches-2 3769-1.html

[20] Hanson, G., Tejral, R., Hunt, S. and Temple, D. (2010) Internal Erosion and Impact of Erosion Resistance. 30th Annual USSD Conference, Sacramento, 12-16 April 2010, 773-784.

[21] McCook, D. (2004) A Comprehensive Discussion of Piping and Internal Erosion Failure Mechanisms. Proceedings of the 2004 Annual Association of State Dam Safety Officials, 1-6.

[22] Islam, M.N. (2000) Embankment Erosion Control: Towards Cheap and Simple Practical Solutions for Bangladesh. 2nd International Conference on Vetiver (ICV2), 2000, 307-321.

[23] Hoque, M.M. and Siddique, M.A.B. (1995) Flood Control Projects in Bangladesh: Reasons for Failure and Recommendations for Improvement. Disasters, 19, 260-263.

[24] Ismail, F., Mohamed, Z. and Mukri, M. (2008) A Study on the Mechanism of Internal Erosion Resistance to Soil Slope Instability. Electronic Journal of Geotechnical Engineering, 13.

[25] Hahn, W., Hanson, G.J. and Cook, K.R. (2004) Breach Morphology Observations of Embankment Overtopping Tests. Joint Conference on Water Resource Engineering and Water Resources Planning and Management, Minneapolis, 30 July-2 August 2000, 1-10.

[26] Clarke, D. and Smethurst, J. (2010) Effects of Climate Change on Cycles of Wetting and Drying in Engineered Clay Slopes in England. Quarterly Journal of Engineering Geology and Hydrogeology, 43, 473-486. http://dx.doi.org/10.1144/1470-9236/08-106

[27] Rogers, L.E. and Wright, S.G. (1986) The Effects of Wetting and Drying on the Long-Term Shear Strength Parameters for Compacted Beaumont Clay. Center for Transportation Research, Bureau of Engineering Research, University of Texas at Austin, Texas.

[28] Lammeranner, W. and Meixner, H. (2008) Woody Plants on Floods Protection Levees: A Contradiction? The Use of Vegetation to Improve Slope Stability. 2nd International Conference on Ground Bio-Engineering, Beijing, 14-18July 2008.

[29] Rajput, M.I. (2010) Translated from Sindhi Book (Sindhu jee Saar). Sindh National Academy (Trust), Hyderabad.

[30] Hanson, G. and Hunt, S. (2006) Determining the Erodibility of Compacted Soils for Embankment Dams. Proceedings of the 26th Annual USSD Conference, San Antonio, 1-6 May 2006, 311-320.

[31] Wan, C.F. and Fell, R. (2004) Investigation of Rate of Erosion of Soils in Embankment Dams. Journal of Geotechnical and Geoenvironmental Engineering, 130, 373-380. http://dx.doi.org/10.1061/(ASCE)1090-0241(2004)130:4(373)

[32] Foster, M. and Fell, R. (1999) A Framework for Estimating the Probability of Failure of Embankment Dams by Internal Erosion and Piping Using Event Tree Methods. University of New South Wales, Kensington.

[33] Foster, M. and Fell, R. (2000) Use of Event Trees to Estimate the Probability of Failure of Embankment Dams by Internal Erosion and Piping. Proceedings of the 20th International Congress on Large Dams, Beijing, International Commission on Large Dams (ICOLD), Paris, Question 76, 1, 237-260.

[34] Hanson, G. and Hunt, S. (2007) Lessons Learned Using Laboratory JET Method to Measure Soil Erodibility of Compacted Soils. Applied Engineering in Agriculture, 23, 305. http://dx.doi.org/10.13031/2013.22686

[35] Wahl, T.L., Lentz, D.J. and Feinberg, B.D. (2011) Physical Hydraulic Modeling of Canal Breaches. Hydraulic Laboratory Report HL-2011-09, Bureau of Reclamation, US Department of the Interior, Denver.

[36] Sjoerd, W.D. (2004) Effects of Soil Compaction. http://pubs.cas.psu.edu/freepubs/pdfs/uc188.pdf

[37] Hughes, A.K. (1981) The Erosion Resistance of Compacted Clay Fills in Relation to Embankment Overtopping. Ph.D. Thesis, Newcastle University, Newcastle.

[38] Giglou, A.N. and Zeraatparvar, A. (2012) Seepage Estimation through Earth Dams. Journal of Basic and Applied Scientific Research, 2, 7861-7865. 